\title{
Studieplanlægning ved lægeuddannelserne
}

\author{
Anne Mette Morcke, lektor, ph.d., Center for Medicinsk Uddannelse, Aarhus Universitet, \\ Gitte Wichmann-Hansen, lektor, ph.d., Center for Medicinsk Uddannelse, Aarhus Universitet \\ Berit Eika, professor, ph.d., Center for Medicinsk Uddannelse, Aarhus Universitet
}

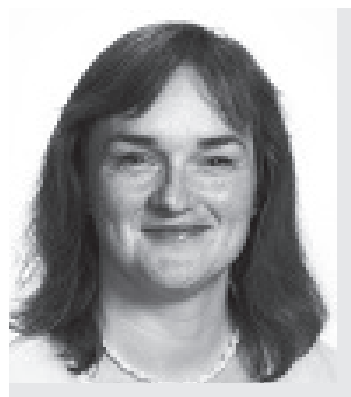

og målbeskrivelse.
Anne Mette Mørcke er læge, ph.d. i uddannelsesforskning og lektor ved Center for Medicinsk Uddannelse, Aarhus Universitet. Anne Mette Mørcke underviser og forsker i sundhedsvidenskabelig fagdidaktik med særlig fokus på undervisningsplanlægning, curriculum

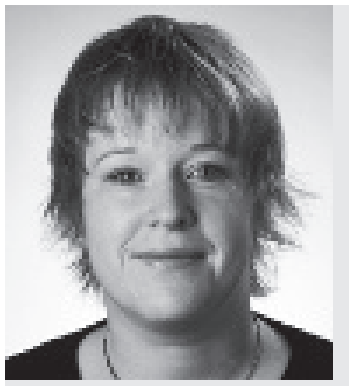

Gitte Wichmann-Hansen er cand.mag. i pædagogik, ph.d. i uddannelsesforskning og lektor ved Center for Medicinsk Uddannelse, Aarhus Universitet. Gitte Wichmann-Hansen underviser og forsker i vejledning - både vejledning knyttet til arbejdspladsoplæring og vejledning i relation til opgave-, projekt- og forskningsforløb på universitetet.

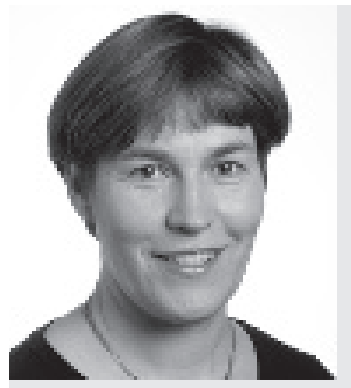

Berit Eika er læge, ph.d., master of health professions education og professor ved Center for Medicinsk Uddannelse, Aarhus Universitet. Berit Eika leder Center for Medicinsk Uddannelse, hvis formål er at bidrage til kvalitetsudvikling af de sundhedsvidenskabelige uddannelser på Aarhus Universitet. Dette sker gennem forsknings- og udviklingsprojekter, kursustilbud og rådgivningsopgaver.

\section{Reviewet artikel}

Vi undersøgte lektorers og undervisningsansvarliges rolle $i$ studieplanlogning ved de tre danske logeuddannelser. Under individuelle og fokusgruppe-interviews pegede informanterne på studieleders helt centrale rolle og lektorers klart perifere rolle. Lektorernes deltagelse blev beskrevet som personafhoengig, baret af ildsjelene. Denne artikel tilbyder et forste empirisk grundlag for at diskutere studieplanlogningspraksis.

\section{Indledning}

I denne artikel beskrives et casestudie om undervisernes rolle i studieplanlægning. Casens informanter udgøres af lektorer og undervisningsansvarlige fra lægeuddannelserne på de tre danske sundhedsvidenskabelige fakulteter ved Aarhus, Københavns og Syddansk Universitet. Formålet med studiet var at undersøge informanternes antagelser om studieplanlægning og deres rolle i processen. Vi stillede en række forskningsspørgsmål, der kan opdeles i to grupper:

1) Hvordan forstår lektorer og undervisningsansvarlige studieplanlægning? Anvender de en model? Er deres antagelser kompatible med modellen Outcome Based Education (Harden et al., 1999)?

2) Hvordan opleves rollefordelingen i studieplanlægning? Hvordan deltager lektorer i planlægningen af lægeuddannelsens mål, metoder, organisering og evaluering?

De resultater, der omhandlede informanternes forstålse af studieplanlægning og dermed den forste gruppe forskningsspørgsmål er publiceret (Morcke \& Eika, 2009). Morcke \& Eika fandt, at kun en enkelt informant havde en eksplicit model, men at samtlige informanter havde implicitte grundantagelser om studieplanlægning. Blandt informanterne fandtes fem essentielt forskellige grundantagelser om studieplanlægning, som vi døbte en 1) metode-drevet, 2) pragmatisk drevet, 3) indholdsdrevet, 4) mål-drevet og 5) visionsdrevet grundantagelse. Kun de to sidstnævnte var fuldt kompatible med Outcome Based Education, som aktuelt udbredes til lægeskoler i hele verden.

De resultater, der omhandler informanternes rolle $\mathrm{i}$ processen og dermed den anden gruppe forskningsspørgsmål, er primært interessante i en dansk kontekst og rapporteres derfor i denne artikel. 


\section{Metode}

$\mathrm{Vi}$ valgte en kvalitativ metode for at eksplorere antagelser om studieplanlægning uden forudbestemte kategorier.Vores forståelsesramme var inspireret af Miles \& Huberman (1994), hvis tilgang indebærer pragmatisk dataindsamling med en induktiv og systematisk dataanalyse.

Casens informanter var lektorer og undervisningsansvarlige fra lægeuddannelserne på de tre danske sundhedsvidenskabelige fakulteter ved Aarhus, Københavns og Syddansk Universitet fra december 2004 til juni 2005. Informanterne blev udtaget teoridrevet, baseret på kriterierne informationsrigdom, kontekst og maksimal variation. Der blev således ikke tilstræbt statistisk repræsentativitet ved samplingen.

Vi udtog fire centralt placerede ledere fra de tre fakulteter. Alle fire gav tilsagn og blev dybdeinterviewet individuelt med en åben interviewguide (Berry, 2002).

Vi valgte fokusgruppe-interview med de øvrige informanter, som kunne finde det uvant at diskutere studieplanlægning som proces.Vi udtog et studienævn, hvoraf fire medlemmer blev interviewet i én fokusgruppe. Derudover interviewede vi yderligere tre fokusgrupper med henholdsvis 1) fem lektorer fra længerevarende basisfag som anatomi, biokemi og fysiologi, 2) fem lektorer fra kortere parakliniske fag som genetik, mikrobiologi og patologi, samt 3) seks kliniske lektorer fra forskellige lægelige specialer. Hver gruppe blev bedt om at opbygge et "puslespil«. Brikkerne bestod af 36 papirkort med didaktiske grundbegreber (for eksempel Mål), aktører (for eksempel Dekanen), strukturer (for eksempel Fagopdeling), processer (for eksempel Konsensus) samt pile og blanke brikker. Dermed fik informanterne mulighed for at opbygge en model som et konkret fokus for erfaringsudvekslingen.

Vi kodede den transskriberede tekst med softwaren Ethnograph og udviklede kodebogen induktivt. Den endelige kodebog indeholdt 58 koder kategoriseret i fem hovedtemaer: Aktører, Processer, Drivkræfter, Strukturer og Modeller. Denne artikel omhandler temaet Aktører, som indeholder koderne Dekan, Institutleder, Kursusleder, Lektor, Ministerium, Professor, Pædagogisk enhed, Studerende, Studieleder, Studienævn og Timelærer.

Vi kondenserede data og analyserede dem iterativt og systematisk for mønstre og mening. Fem delanalyser danner basis for denne artikel: 1) en frekvensanalyse af samtlige koder, 2) en farvekodning af al transskriberet tekst, 3) en tekstanalyse af alle uddrag kodet både som Aktører og Processer, 4) en matrice over hvilke koder der er kodet sammen med Lektor eller Studieleder, 5) en analyse af de fire fokusgruppers placering af brikkerne i puslespillet.

Som konklusion på ovenstående fem delanalyser kunne vi vise informanternes forståelse af egen og andres rolle i studieplanlægning $\mathrm{i}$ form af figur $1 . \mathrm{Vi}$ har desuden udvalgt seks lange illustrative citater (i resultatafsnittet). Efter hvert citat er i parentes angivet den søgte kode, det vil sige Ethnographs specifikke hitnummer til det citerede tekststykke, samt hvilket interview citatet er fra.

\section{Resultater}

I dette resultatafsnit præsenterer vi informanternes overvejelser om egen og andre aktørers rolle i studieplanlægning på lægeuddannelsen. Hovedfundene var, at studieledere blev opfattet som helt centrale, mens lektorerne var perifere. Resultatafsnittet er opbygget med 1) en kort præsentation af, hvordan fokusgrupperne lagde puslespillet, 2) en uddybning af informanternes syn på de ledende aktørers rolle, samt 3) en uddybning af informanternes syn på lektorernes rolle.

\section{Fokusgruppernes puslespil}

Der var påfaldende ligheder mellem grupperne. Figur 1 viser fællestræk i de fire puslespil. Alle fire fokusgrupper udvalgte først brikker med forskellige aktører og lagde dem. I centrum lagde de: Dekan, Studieleder og Studienævn. Brikken Ministeriet blev lagt af tre af de fire fokusgrupper, mens diverse råd, som for eksempel Akademisk Råd, overhovedet ikke indgik i informanternes puslespil. Alle fire fokusgrupper placerede Lektor-brikken perifert. Brikkerne om forskellige didaktiske valg, som læringsmål, undervisningsorganisering og evaluering placerede de uden for Lektorbrikkens rækkevidde.

Der var også forskelle mellem grupperne. Fokusgruppen med studienævnsmedlemmer opbyggede det mest komplekse puslespil med 29 brikker. Fokusgruppen med kliniske lektorer adskilte sig fra de øvrige ved kun at bruge 10 af brikkerne og placere dem mere uorganiseret.

\section{Informanternes syn på ledende aktorers rolle $i$ studie- planlagningen}

Studieledere var kerneaktører. Denne konklusion baserer sig på fem fund. For det første viste matricen over samkodninger, at næsten alle koder var kodede med Studieleder. For det andet var det markant, at koden Studieleder fik 17 hits i kombination med proceskoden Ledelse, mens for eksempel institutleder kun fik 3 hits og kursusleder 0 hits i samme kombination. For det tredje blev studielederes rolle opfattet af informanterne som meget mangfoldig og blev for eksempel beskrevet med informanternes ord som "forhandler »kompromismager«, "buffer mellem dekan og lektorer«, en der »holdt overblik«, en der »skar igennem« og en »boss«. For det fjerde viste farvekodningen, at studieledere var centrum for en stor del af fokusgruppernes diskussioner, både i tid og intensitet. Endelig beskrev også de undervisningsansvarlige informanter studieleder som en helt central aktør.

Informanterne beskrev en klar hierarkisk forbindelse 


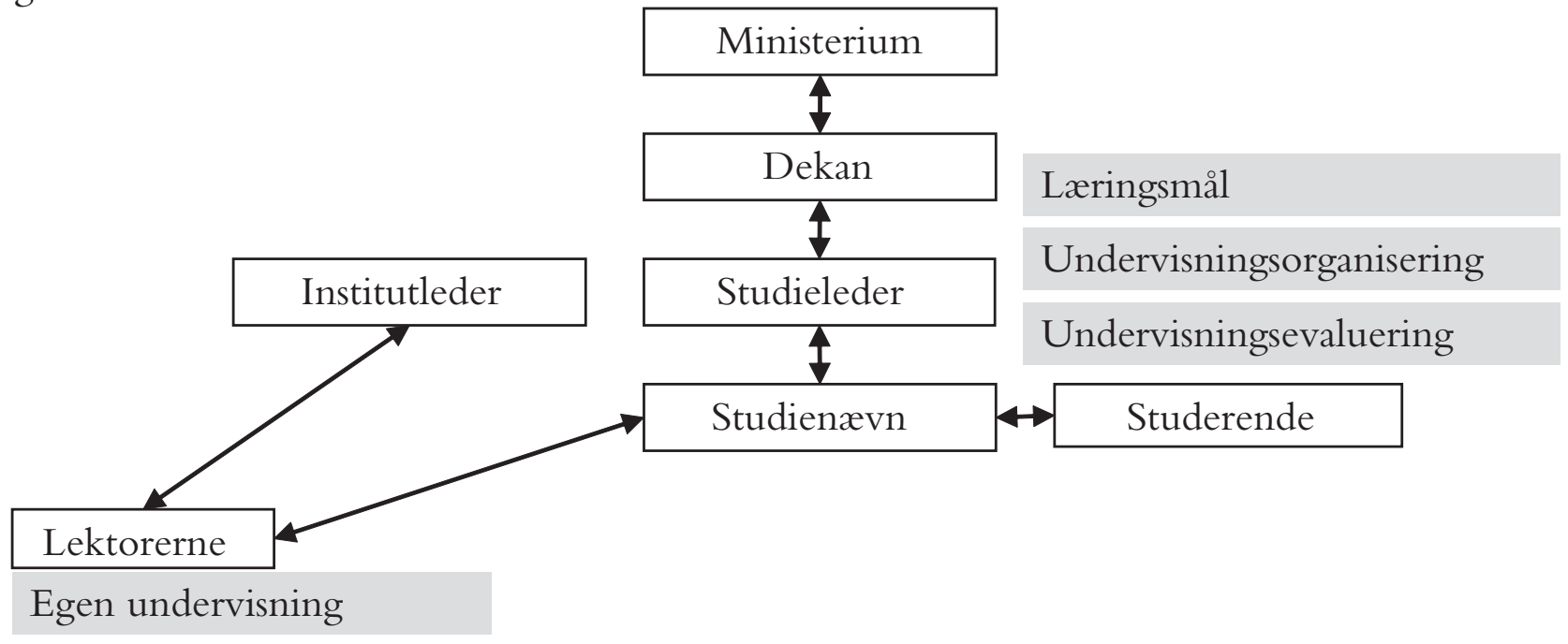

mellem studieleder og dekan. Rollefordelingen mellem studieledere og institutledere var derimod mere uafklaret for informanterne. En af de undervisningsansvarlige beskrev for eksempel sit syn på forholdet mellem studieleder, dekan og institutleder således:

U1: "Studielederen har jo ret, men ogsa forpligtigelse, til at sorge for, at dekanen bliver fodret rigtigt med de nye ting, der nu er her. Det er jo studielederens forpligtigelse, selvom det efterhånden bliver mere og mere bare evaluering. Det går jo mere og mere over på institutlederne. Så hvis ikke man far en studieleder, der er accepteret og vellidt af aktorerne, så kan institutlederne efterhånden bare kore udenom ham. Så hvis institutlederne synes, at studielederen sådan set bare er en kransekagefigur og tilmed ubegavet og alt sådan noget, så tror jeg ikke, at du kan... Så fär studielederen ingen indflydelse."

(Ethnograph søgekode: studieleder, hit 10, elite interview 1)

Som illustreret af ovenstående citat var rollefordelingen mellem institutleder og studieleder noget uklar, selvom der klart blev givet udtryk for, at studieleder ikke kan planlægge lægeuddannelsen uden institutledernes klare opbakning. Den samme ambivalens var også indbygget i studienævnets rolle. Som eksempel herpå vises nedenfor et citat, hvor en anden af de undervisningsansvarlige overvejede rollerne:

U2:»Men studiencevnet kan jo selvfolgelig ikke lave noget uden institutterne. (...) Det er studiencevnet, der fastloegger studieordningen. Men de kan jo umuligt gøre det uden et samarbejde. Så kommer vi jo sådan set ind på det, du skriver: (læser op) Er konsensus om studieplanen vesentligt? For mig er det."

Interviewer: "For at det fungerer?"

U2: "Det tror jeg faktisk. Alle involverede parter har påtaget sig et medansvar. At man ikke siger til nogen: $\mathrm{Nu}$ skal I altså undervise på den måde, og I skal integrere jer, uden at de er med. Jeg tror faktisk, at det er meget vanskeligt. For studiencevnet kan jo bestemme så meget $i$ princippet, men det er jo institutterne, der skal gore det." (Ethnograph søgekode: studienævn, hit 15, elite interview 2)

Som illustreret af ovenstående citat var også rollefordelingen mellem studienævn og institutter uklar: Studienævnet bestemmer 'i princippet' - men kan i praksis umuligt gennemføre noget uden om institutlederne. Paradoksalt opfattede informanterne dog ikke institutledere som undervisningsledere. Kun i fire af de 14 hits på institutledere blev de klart beskrevet i den rolle. Sammenfattende opfattede informanterne studieleder som central for studieplanlæegning på lægeuddannelsen med en vifte af opgaver og roller, men med en noget uklar ansvarsfordeling $\mathrm{i}$ forhold til institutlederne.

\section{Informanternes syn på lektorernes rolle $i$ studieplan- loegningen}

Lektorerne var perifere. Denne konklusion baserer sig på tre fund. For det første placerede samtlige fokusgrupper konsekvent Lektor-brikken perifert i puslespillet. For det andet beskrev informanterne lektorernes rolle som perifer, hvilket illustreres i de efterfølgende citater. For det tredje fik aktør-koden Lektor ganske vist mange (95) hits, men det var primært lektorerne, der talte om sig selv (82 af de 95 hits). De undervisningsansvarlige informanter forholdt sig kun til lektorernes rolle, når de blev direkte adspurgt herom. For eksempel svarede en af de undervisningsansvarlige direkte adspurgt om den enkelte lektors indflydelse på studieplanen:

U1: "Det er personafhoengigt. Der er nogle ildsjele jo. Hvis de så vil, så kan de. Så har de muligheden for at gå igennem deres undervisningsudvalg på instituttet, og så den vej fä professoren $i$ tale, eller over kaffebordet, eller på skovturen. Det kan de helt klart. Ja, det mener jeg. 
Jeg vil sige, at selv den yngste student kan fä indflydelse. Det kan godt vare, at du lober panden mod en mur en gang imellem, men jeg vil sige, at der er bestemt... Det er det, jeg mener med demokratiet, altså. Nogen steder er det mere demokratisk end andre steder, men jeg mener bare, at der er fri adgang. Der er ikke lukkede dore nogen steder." (Ethnograph søgekode: lektor, hit 24, elite interview 1)

Som ovenstående citat illustrerer, så mente undervisningsansvarlige informanter klart, at lektorer som personlige ildsjæle kan få indflydelse på studieplanlægningen via for eksempel undervisningsudvalg. Også lektorerne pegede på, at den enkelte lektors indflydelse kunne opfattes som meget personafhængig. I nedenstående diskussion talte en fokusgruppe først om det personafhængige og fortsatte diskussionen derfra således:

E: "Der vil jeg da sige, at alting er personafhoengigt. I den der kommunikation, der er det jo ikke alle, der hedder det der (peger på lektor brikken), der får den kommunikation der. Så det er personafhoengigt $i$ det hele taget, hvad der foregår på det her fakultet, ikke? Det er sådan en overordnet trend. Det mener jeg helt klart.«

Interviewer: " $S a ̊$ når $C$ siger, at han var hoegtet af, så er det nok rigtigt? «

C: "Det er nok også det, at jeg ikke rigtigt kan huske, hvordan det var, men jeg kan bare huske, at det (en bestemt studieændring) kom.«

Interviewer: "Så nogle af lektorerne kunne vi måske putte helt herud? (flytter lektorbrikken lidt længere ud til siden)

$\mathrm{C}:$ "Ja, det må vi nok sige."

$\mathrm{E}:$ "Det synes jeg helt klart.«

C: „Der er nogen... Jeg vil ikke sige, at jeg var ninteresseret, men altså...

Interviewer: "Perifer på en eller anden måde?"

$\mathrm{C}:$ "Meget perifer må man nok sige. "

$\mathrm{B}$ : "En der blokerer lidt herude, ikke? (snak i munden på hinanden)

(Ethnograph søgekode: lektor, hit 6, fokusgruppe A)

Som ovenstående citat også illustrerer, så associerede informanterne fra 'personafhængig' til 'perifer' til 'en der blokerer.' Lektorer, der blokerer eller går i forsvarsposition, blev taget op mange gange af informanterne. De interviewede lektorer havde et skarpt blik for deres egen modstand mod forandringer, men udtrykte alligevel ofte behov for at forsvare sig over for nogle, i deres øjne, uforståelige krav. Frygten for ubehageligheder lusket ind ad bagdøren var gennemgående i deres beskrivelser, og bønnen om klar information blev gentaget igen og igen. For eksempel da en informant foreslog, at studieleder kunne fortælle, hvad der skulle ske, hvilket udløste nedenstående udveksling i gruppen:
$\mathrm{J}$ : "Studieleder kunne for eksempel komme rundt til de forskellige institutter."

I: »Der kunne jo godt blive holdt et stort mode, så alle fik noget generel information."

$\mathrm{J}: » J o$, men så kunne studieleder bagefter gøre det andet, for det ville vare rart nok selv at kunne sige sin mening der." G: »Det er jo klart, at hvis de har en ide om - og det kunne jo vore, at de ved noget, som vi ikke ved her - så er det jo rimeligt, at det bliver delt med os. Hvis man ikke ved, hvordan man skal gribe det an, så er det også meget rimeligt at laggge det frem, og sige hvis det nu er sådan, at det er et krav, at det kan vi ikke undgå, og sådan må det nødvendigvis vare. Jeg ved godt, at så lyder det jo ligesom før, men når det nu kommer helt dernede fra Bruxelles og alt sådan noget.«

I: "Ja, der er langt ned."

G: "Ligesom agurkerne der ikke må vare krumme. Så var det jo rart, at vi alle sammen ved det. På den måde kan vi også vare mere konstruktive $i$ stedet for destruktive om, hvad det er vi skal forholde os til, for når man fä det ind sådan lidt ad bagdoren, så bliver man jo destruktiv. Det eneste man nosten - $i$ hvert fald ubevidst - tonker på, det er at forsvare sig selv. "

$\mathrm{F}: " J a$, det er rigtigt."

(Ethnograph søgekode: studieleder, hit 22, fokusgruppe B)

Som ovenstående citat illustrerer, så følte informanterne sig perifere $i$ forhold til at få information og at 'kunne sige sin mening' derom; og de erkendte den destruktive forsvarsposition ved studieændringer. Når lektorerne selv talte om egen rolle, så gav de klart udtryk for, at de oplevede deres indflydelse som begrænset. Det blev for eksempel udtrykt således:

I: "Jamen, det kan så også vore, at der er nogen ting, som de (studienævnet) er fuldstondig ligeglade med. Menaltså - vi har bare oplevet, at hvis vi kommer over og siger, at vi vil have det lavet om: Hvor mange var det, der bestod sidste gang? De bestod noesten alle sammen. Na! Hvad er problemet så? Hvis det går godt nok, hvorfor skal de så hore på en eller anden tilfoeldig lektor, der kommer og beder om nogle andringer?"

(Ethnograph søgekode: studerende, hit 78, fokusgruppe B)

Som illustreret af ovenstående citat, så brugte lektorer udtryk som 'fuldstændig ligeglade' og 'tilfældig lektor' om egen indflydelse på studieplanen. Sammenfattende kunne ildsjæle blandt lektorerne få stor indflydelse, men generelt blev lektorernes rolle opfattet som perifer i planlægningen af lægeuddannelsen.

\section{Diskussion og konklusion}

Formålet med dette studie var at undersøge lektorers og undervisningsansvarliges antagelser om studieplan- 
lægning på lægeuddannelsen: Hvordan opleves rollefordelingen? Hvem menes at have indflydelse? Hvordan deltager lektorer i planlægningen af uddannelsens mål, metoder, organisering og evaluering? Informanterne opfattede studieleder som central for studieplanlægning på lægeuddannelsen med en vifte af opgaver og roller. De opfattede samtidig lektorernes rolle som perifer i planlægningen. Rollefordelingen mellem alle øvrige aktører i studieplanlægningen blev under dekanniveau beskrevet som flad og noget uklar for informanterne. Det gjaldt for eksempel aktører som institutledere, professorer, samt diverse udvalg og råd.

Man kan spørge, om der er noget nyt i det fund? Der er naturligvis skrevet meget om curriculum reformer og studieplanlægning, men der er ingen empiriske undersøgelser af, hvordan lægeuddannelsens aktører i praksis deltager og hvilken rolle de har. En enkelt international og en enkelt dansk artikel rejser spørgsmålet, men har ikke direkte undersøgt hverken underviseres eller undervisningsansvarliges egne antagelser og perspektiver på rollerne (Hoat et al.; 2007, Mørcke et al.; 2008). Denne undersøgelse tilbyder dermed et første empirisk grundlag for diskussioner af praksis.

Ifølge Miles \& Hubermans (1994) kriterier har dette casestudie en høj grad af bekræftelighed og transparens, men vi kan naturligvis ikke afvise, at det kun skulle være informanterne i dette casestudie, der ser egen og andres rolle i studieplanlægning som beskrevet. De 24 informanter er udtaget med henblik på maksimal variation inden for casens rammer. Undersøgelsens generaliserbarhed kan derfor principielt kun vurderes i den kontekst, som resultaterne eventuelt måtte forsøges overført til. Med dette forbehold in mente vil vi pege på, at resultaterne af dette casestudie naturligvis kan fortolkes og diskuteres på andre universitetsuddannelser, hvor lektorer og studieledere - alle forskellene til trods - jo også har deres rolle i undervisning og studieplanlægning.

Studieledere blev af informanterne beskrevet som centrale i studieplanlægning i en vifte af roller. Samtidig havde de en temmelig uklar opgavedeling i forhold til ikke mindst institutledere. En tilsvarende vifte af roller og uklare opgaver er fundet i den postgraduate lægeuddannelse, hvor Malling og kolleger (2007) har undersøgt uddannelsesansvarlige overlægers rolle og konkluderede, at der var behov for en mere entydig undervisningsledelse, funktionsbeskrivelser og efteruddannelse. Det er derfor opmuntrende, at der siden 2006 er blevet gennemført landsdækkende studielederkurser, som har fokus på universitetspædagogik, organisation og ledelse. ${ }^{1}$ Behovet for funktionsbeskrivelser og mere entydighed i undervisningsledelsen bør dog også overvejes. Ifølge Universitetsloven $\mathbb{1} 18$, stk. 5 har studielederen "til opgave $i$ samarbejde med studiencevnet at forestå den praktiske tilrettelaggelse af undervisning og af prover og anden bedømmelse, der indgär i eksamen. Studielederen godkender opgaveformulering og afleveringstidspunkt for kandidatspecialet samt $i$ tilknytning hertil en plan for vejledningen af den studerende. "Den eneste veldefinerede opgave til studieleder er således at vedkommende skal godkende kandidatspecialeplaner. I lyset af studieleders helt centrale rolle i studieplanlægning i en tid med konstante krav om studieændringer, bør man nok igen diskutere, om en så upræcis formel organisatorisk placering og funktionsbeskrivelse stadig er tilstrækkelig.

Lektorernes rolle i studieplanlægning blev af informanterne beskrevet som perifer. Efter afslutningen af denne undersøgelse er den nye Universitetslov blevet implementeret. Man kan derfor spørge, om lektorernes rolle dermed er ændret? Det tror vi ikke, for Universitetsloven beskæftiger sig ikke med lektorer eller undervisere mere generelt. De nævnes faktisk slet ikke på noget tidspunkt i loven. ${ }^{2}$

Perspektiverende vil vi afslutningsvist fremhæve kapitel $5 \mathrm{i}$ antologien Globalisation and Reform in Higher Education, som diskuterer forskydninger i undervisernes rolle udløst af globaliseringen (Morey; 2003). Morey ridser en række udfordringer op og blandt andet skriver hun: "Fundamental to university faculty is the personal autonomy faculty members enjoy in their teaching and research. It contributes to their sense of identity and is a primary source of work motivation and satisfaction. But this notion that faculty have control over all aspects of their teaching and research is being challenged by the new realities. For example, academic work in traditional and for-profit higher education is being unbundled with groups of specialists and other providers assuming specific tasks, such as curriculum design, teaching, instructional materials development and assessment« (p. 80). Morey stiller altså spørgsmålstegn ved om undervisernes autonomi og dermed motivation er truet. På 'det traditionelle universitet' har den enkelte lektor stor grad af autonomi i sin forskning og undervisning. Men er vi på vej $\mathrm{i}$ en retning, hvor autonomien erstattes med afmagt i 'det globaliserede universitet' med centraliserede krav fra Bologna-processen og den medfølgende målstyring og kontrol? Det er selvfølgelig sat på spidsen, men vi finder det bekymrende, at vore informanter placerede lektorerne udenfor beslutningsvejene $\mathrm{i}$ forhold til studieplanlægning. Det kan potentielt give lektorer en uheldig rolle som på en gang autonome og afmægtige. Den gode vilje er til stede, men udfordringen ligger $i$ at revitalisere lektorernes involvering $i$ en tid med Bologna-proces, kvalitetssikringssystemer og centralisering af studieadministrationen.

\section{Tak}

Tak til alle vore informanter, fordi de lod os få et inspirerende indblik i deres overvejelser om god uddannelse og planlægning heraf.

\section{Referencer}

Berry JM. (2002).Validity and reliability issues in elite interviewing. Political Science and Politics, 35, pp.679-682. 
Harden RM, Crosby JR, Davis MH. (1999). AMEE Guide No 14: Outcome-based education. Association of Medical Education Europe.

Hoat LN,Yen NB, Wright EP. (2007). Participatory identification of learning objectives in eight medical schools in Vietnam. Medical Teacher, 29: 683-690.

Malling B, Scherpbier AJJA, Ringsted C. (2007). What is the role of the consultant responsible for postgraduate education in the clinical department? Medical Teacher, 29: 471-477.

Miles MB, Huberman AM. (1994) Qualitative data analysis. UK, Sage.

Morcke AM, Eika B. (2009). Medical faculty and curriculum design - 'No, no, it's like this: you give your lectures...' Medical Teacher, 31 (7): 642-648.
Morey, AI. (2003). Major trends impacting faculty roles and rewards: an international perspective. In: Eggins, H. (2003). Globalisation and Reform in Higher Education. GBR, McGraw-Hill Education.

Mørcke AM, Wichmann-Hansen G, Eika B. (2008). Aarhus Universitet på vej mod målrettet uddannelse. Ugeskrift for Lager, 170 (44): 3525-3528.

\section{Noter}

1 http://www.sdu.dk/Uddannelse/Efter_videreuddannelse/ Korte kurser/Studielederkursus.aspx

2 https://www.retsinformation.dk/Forms/R0710.aspx?id $=127797$ 